\title{
Corelation of Stress Levels During Covid-19 Pandemic and Menstrual Cycle of Diploma IV Midwifery Student of Sebelas Maret University
}

\author{
Indi Nareswari ${ }^{*}$, Hudzaifah Alief Fath Azizah ${ }^{1}$, Murniasih ${ }^{1}$, Ruth Dearani \\ Sinaga ${ }^{1}$, Revi Gama Hatta Novika ${ }^{1}$, Atriany Nilam Sari ${ }^{1}$ \\ ${ }^{1}$ Diploma 4 Midwifery Study Program, Faculty of Medicine, Sebelas Maret University \\ Ir. Sutami 36 A, Kentingan Surakarta 57126 phone. (0271) 662622 \\ * Corresponding author \\ E-mail: indinareswari2017@gmail.com
}

\begin{abstract}
The pandemic period caused by the SARS-CoV2 virus is a global problem that has an impact on the community, including students. Task load and online learning systems are factors that cause students to experience stress, this can be one of the causes of disruption of the menstrual cycle. Changes in the menstrual cycle is a health problem for some women. This study aims to link stress levels during the coronavirus disease 19 pandemic to the menstrual cycle of UNS Diploma IV Midwifery students.This study analyzed primary data of observational analytic with a cross sectional design. The independent variable in this study was stress on students, while the dependent variable in this study was changes in the menstrual cycle. We used 84 sample consisting of all midwifery student in Sebelas Maret University with an age range of 17-22 years. There is no relationship between stress during the coronavirus disease 19 pandemic and student menstrual cycles with a $p$ value of 0.925 indicating that there is no significant relationship between the two variables tested $(p<0,05)$. There is no significant relationship between stress levels during the pandemic and the menstrual cycle of UNS midwifery diploma IV students.
\end{abstract}

Keywords: Stress, Menstruation, Student

\begin{tabular}{l}
\hline INTRODUCTION \\
The Horld Health \\
Organization (WHO) since 2019 has stated \\
that the current condition is a global public \\
health emergency, this is based on the \\
emergence of coronavirus in all corners of \\
the world including in \\
Indonesia ${ }^{(1)}$. Coronavirus disease 2019 \\
(Covid-19) is an infectious disease caused \\
by SARS-CoV2 with morbidity and \\
mortality in Indonesia that continues to
\end{tabular}

increase. In addition to having an impact on physical health, namely acute respiratory disorders, another result caused is psychological disorders in the form of stress. This is triggered by the government's policy to carry out Large-Scale Social Restrictions (PSBB) with various programs including implementing health protocols such as wearing masks, washing hands, maintaining distance or social distancing and the enactment of the Work 
from Home system and Study From Home. All activities are conducted online or not face-to-face directly including lectures. In this situation, students of the Diploma IV Midwifery study program uns became one of the subjects who felt the impact of the coronavirus disease pandemic 19 (Covid-19) in the form of psychological disorders, namely stress.

In times of pandemics, stress can be classified into 3 scopes: academic stress, work stress, and stress problems in the family. The scope of the former is very potential experienced by students, assignment pressures, signal constraints and internet data packages are factors that may contribute to stress-related psychological problems. Stress can be experienced by anyone, regardless of whether the person is a student or a worker, does not look at the age of whether children, teenagers, or parents. According to WHO (2003) Stress is the body's reaction to psychosocial stress (mental stress/ burden of life). The impact of stress according to Bressert (2016), in view of the physical aspects, among others, sleep disturbances, increased heart rate, muscle tension, dizziness, fever and fatigue. The impact on cognitive aspects is characterized by confusion, reduced memory, worry, and panic. In addition to the emotional aspect, the impact of stress is characterized by irritability, sensitivity, frustration, and feeling helpless. In the behavioral aspect, the impact of stress causes a tendency to be non-social, alone, the desire to avoid others and the onset of laziness ${ }^{(2)}$.

According to Santrock (2008) the stage of student development is at the level of young adulthood, at this stage students try to explore themselves to find identity, build social circles, and understand emotional changes $^{(2)}$. In this case such students have a fortress that limits their psycho-social development in society, due to various limitations during the ongoing pandemic in the past year. Supported by supporting factors during the Covid-19 pandemic, students are most likely to experience stress disorder. The part of the brain that responds to the release of corticotrophin releasing hormone $(\mathrm{CRH})$ and stimulates the anterior pituitary to secrete adrenocorticotropic hormone $(\mathrm{ACTH})^{(3)}$. This hormone stimulates the adrenal cortex for the secretion of cortisol or commonly called stress hormones produced in the adrenal glands that are above the kidneys. Cortisol is then released into the blood and flowed throughout the body. Increased cortisol secretion will affect gnrh secretion in the hypothalamus, thus affecting the menstrual cycle $^{(3)}$. Changes in the normal pattern of hormones will interfere with a woman's ovulation cycle so that the menstrual cycle becomes changed or irregular.

According to Proverawati (2009), Perry (2010) Menstruation is periodic and cyclic bleeding from the uterus accompanied by the release (deuamasi) of the endometrium. The process of menstruation occurs through four stages, namely the menstrual phase, proliferation phase, luteal / secretion phase, and ischemic phase. Studies state that women of reproductive age have problems with abnormal menstruation such as premenstrual syndrome, irregular menstruation, dysminorea, and menoragia.

\section{RESEARCH METHODS}

This study is an analytical observational study with cross sectional design. The free variable in the study was stress, while the bound variables in the study were changes in the menstrual cycle. The population in this study is midwifery student of Sebelas Maret University with an age range of 17-22 years. We used 84 sample with total sampling. Data collection using instruments in the form of online questionnaires by Kessler Psychologycal Distres Scale, this study consisted of 10 questions.

Stress levels are categorized as follows:

a. Score under 20: no stress

b. Score 20-24: mild stress

c. Score 25-29: moderate stress

d. Score 30 and above 30: severe stress 
The pattern of the menstrual cycle is measured by a questionnaire of the menstrual cycle. Researchers classified it into four as below:

1. Normal cycle if the menstrual cycle ranges from 24-38 days.

2. Shortening cycle or polymenorea if the menstrual cycle $<24$ days.

3. Elongated cycle or oligomenorrhea if the menstrual cycle $>38$ days.

4. Amenorrhea if you do not menstruate for 3 months in a row.

Data analysis in this study uses univariate analysis to look at frequency distribution, while bivariate analysis to see the relationship between free and bound variables using the SPSS 25 program with the Spearman Rank Correlation statistical test.

\section{RESULT}

This research was conducted on 84 active Midwifery students of Sebelas Maret University Surakarta from class 20192018. The study was conducted in January by providing questionnaires filled out online using google form.

Socio-Demographic Characteristics of Respondents

Table 1. Characteristics of Respondent Distribution

\begin{tabular}{lcc}
$\begin{array}{c}\text { Category } \\
\text { Age Range } \\
\text { (years) }\end{array}$ & $\begin{array}{c}\text { Drequency } \\
\text { (n) }\end{array}$ & $\begin{array}{c}\text { Percentage } \\
(\mathbf{\%})\end{array}$ \\
\hline 17 & 1 & 1 \\
18 & 27 & 32 \\
19 & 19 & 23 \\
20 & 24 & 29 \\
21 & 12 & 14 \\
22 & 1 & 1 \\
Total & $\mathbf{8 4}$ & $\mathbf{1 0 0}$ \\
Domicile & & \\
Central Java & 55 & 65 \\
East Java & 16 & 19 \\
West Java & 6 & 7 \\
Yogyakarta & 3 & 4 \\
Jakarta & 1 & 1 \\
Bengkulu & 1 & 1
\end{tabular}

Central 2

Kalimantan

Total

84

100

Respondents were in the age range of 17-22 years, with the largest number of 18year-olds. The domicile of the most respondents was in Central Java, which was 55 people $(65 \%)$.

Table 2. Univariate Analysis

\begin{tabular}{lcc}
\hline $\begin{array}{c}\text { Category of } \\
\text { Stress Levels }\end{array}$ & $\begin{array}{c}\text { Frequency } \\
(\mathbf{n})\end{array}$ & $\begin{array}{c}\text { Percentage } \\
(\boldsymbol{\%})\end{array}$ \\
\hline Not stressed & 13 & $15 \%$ \\
Mild stress & 19 & $23 \%$ \\
Moderate & 29 & $35 \%$ \\
stress & & \\
Severe stress & 23 & $27 \%$ \\
Total & 84 & $100 \%$ \\
Menstrual & & \\
Cycle & & \\
Normal & 72 & $86 \%$ \\
Polymenorea & 7 & $8 \%$ \\
Oligomenorrhea & 5 & $6 \%$ \\
Amenorea & 0 & $0 \%$ \\
Total & $\mathbf{8 4}$ & $\mathbf{1 0 0 \%}$ \\
\hline
\end{tabular}

\section{Univariate Analysis}

Table 2 shows respondents with a moderate stress levels of 29 people (35\%), and severe stress levels of 23 people (27\%). 
Table 3. Bivariate Analysis

\begin{tabular}{|c|c|c|c|c|c|c|c|c|c|}
\hline $\begin{array}{l}\text { Category } \\
\text { of Stress }\end{array}$ & & & ens & trua & 10 & ycle & & & \\
\hline & 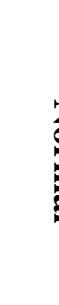 & & & & & 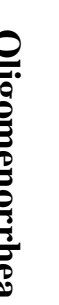 & 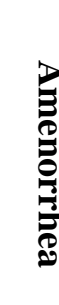 & : & \\
\hline & $\mathbf{n}$ & $\%$ & $\mathbf{n}$ & $\%$ & $\mathbf{n}$ & $\%$ & $\mathbf{n}$ & $\%$ & \\
\hline $\begin{array}{c}\text { Not } \\
\text { stressed }\end{array}$ & 12 & 14 & 1 & 1 & 0 & 0 & 0 & 0 & \\
\hline $\begin{array}{l}\text { Mild } \\
\text { stress }\end{array}$ & 14 & 17 & 2 & 2 & 3 & 4 & 0 & 0 & \\
\hline $\begin{array}{l}\text { Moderate } \\
\text { stress }\end{array}$ & 26 & 31 & 3 & 4 & 0 & 0 & 0 & 0 & \\
\hline $\begin{array}{c}\text { Severe } \\
\text { stress }\end{array}$ & 19 & 23 & 1 & 1 & I & 4 & 0 & 0 & \\
\hline
\end{tabular}

\section{Bivariate Analysis}

Table 3 shows non-stressed respondents data with a normal menstrual cycle of 12 people (14\%). Mild stress respondents with a normal menstrual cycle of 14 people (17\%). Moderate stres respondents with a normal menstrual cycle of 26 people $(31 \%)$. While the respondents were severely stressed with a normal menstrual cycle of 19 people (23\%).

The results of statistical tests using the SPSS 25 Cholera Spearman Program obtained a $\mathrm{p}$ value of 0.925 showing that there is no meaningful relationship between the two variables tested $(p<0.05)$.

In the time of the Covid-19
pandemic, students with all their duties can experience stress. Stress is an organism's response to adjust to its ongoing demands. According to Sri Kusmiati and Desminiarti based on the cause of stress classified into 3 types, namely physical stress, caused by conditions of temperature that is too high or low, light that is too bright, noise, and stung by the flow of electric currents, while chemical stress is caused by chemicals such as drugs, toxic substances, and parasites that cause disease, then physiological stress is caused due to structural disorders, tissue function, organs, or systemic causes disorders of body function $^{(4)}$.

Stress can affect the pattern or menstrual cycle by activating the Hypothalamus Pituitary Adrenalin Axis (HPA-ax) then the hypothalamus secretes Corticotropic Releasing Hormone (CRH) which has a negative influence so that it inhibits the secretion of Gonodrotropin Releasing Hormone (GnRH) hypothalamus which results in inhibition of FSH-LH secretion from the pituitary, so corticotropic imbalance releasing hormone $(\mathrm{CRH})$ can affect the suppression of reproductive function in women ${ }^{(5)}$.

Menstruation is periodic bleeding and cyclic along with endometrial release ${ }^{(6)}$. Women's menstrual cycles are divided into three types: polymenorea is a menstrual cycle of less than 24 days, normal with menstrual cycles between 24-38 days and oligomenorrhea with menstrual cycles of more than 38 days $^{(7)}$.

The predecessor study that the author conducted on 84 students of D4 Midwifery UNS obtained the results of statistical tests using the SPSS 25 Cholera Spearman Program obtained results with a value of $p$ value of 0.925 . These values showed no significant association between stress during the Covid-19 pandemic and the menstrual cycle in female students.

Based on previous studies found similar research conducted by Nurul Aini Yudhita, et al. in the publication of a journal involving students of the Faculty of Medicine, Andalas University used 112 samples that showed the results of data analysis with Fisher's exact test with a significance level of 0.05 . In this study obtained $p$-value $=0.616$ which means that there is no meaningful relationship between stress and menstrual cycle patterns ${ }^{(8)}$.

This also supported by Atma Deviliawati's research conducted at SMAN 
1 Rambutan, Banyuasin Regency on November 4 to November 30, 2019 with a sample of 143 people. The results showed that there was no significant relationship between stress and the menstrual cycle, with p-value $=0.312^{(9)}$.

\section{CONCLUSION}

Based on the results of the study it can be concluded that there is no significant association between stress levels during the Covid-19 pandemic and changes in the menstrual cycle of students with a value of $p$-value of $0.925(\mathrm{p}<0.05)$.

\section{ACKNOWLEDGMENTS}

This research can be carried out with the help of various parties, therefore the researchers expressed their gratitude especially to the Head of Study Program and Lecturer of D4 Midwifery of Sebelas Maret University, Diploma IV Midwifery students of Sebelas Maret University for providing good support and cooperation in this study, as well as to respondents who had deigned to participate in this study.

REFERENCE
1. Morawska L, Cao J. Airborne
transmission of SARS-CoV-2: The world should face the reality. Environment International. 2020. Available from www.elsevier.com/locate/envint

2. Sugiarti A., Musabiq., Isqi Karimah. Description of stres and its impact on students. Journal of InSight. 2018. Vol 20, No 2.

3. Daisa Rosiana. Hubungan Tingkat Stres Dengan Keteraturan Siklus Menstruasi Pada Remaja Kelas XII di SMK Batik 1 Surakarta. Skripsi. Surakarta: Universitas Muhammadiyah Surakarta; 2016.

4. Musradinur. Stres dan Cara Mengatasinya dalam Prespektif Psikologi. Jurnal Edukasi; 2016.
5. Hapsari A, Lisa PW. Siklus dan Lama Menstruasi Mahasiswa selama Pembelajaran Daring dimasa Pandemi Covid-19. Mimbar Ilmiah Kesehatan Ibu dan Anak; 2020.

6. Prayuni DP, Ario I, Myrna A. Therapy for Irregular Menstruation with Acupunture and Health Herbal Pegagan ( Centela Asiciatica (L)). Journal of Vocation Health Studies; 2018.

7. Munro M G, Critchley H O D, Fraser I S. The two FIGO systems for normal and abnormal uterine bleedings symptoms and classification of causes of abnormal uterine bleeding in the reproductive years. International Journal of Gynecology \& Obstetrics. 143: 393-408; 2018.

8. Yudita N A, Yanis A, Iryani D. Hubungan antara Stres dengan Pola Siklus Menstruasi Mahasiswi Fakultas Kedokteran Universitas Andalas. Jurnal Kesehatan Andalas. Vol.6, No.2; 2017.

9. Deviliawati, A. Hubungan Stres dan Siklus Menstruasi. Jurnal Aisyiyah Palembang. Vol.5, No.2; 2019. 